\title{
An Uncertain Future for the UK's Eco-towns
}

\section{David Sharp}

"...Green space does more than pretty up the neighbourhood; it seems to have real effects on health inequality, of a kind that politicians and health authorities should take seriously". ${ }^{1}$ Terry Hartig, from the Institute for Housing and Urban Research at Sweden's Uppsala University, is here encapsulating the latest British research on this recurrent theme in urban-health medicine. ${ }^{2}$ The trouble is that towns are only occasionally built from scratch and cities hardly ever. Usually, these living-andworking units just grow, and when the enlargement is haphazard or when the planning lacks socially and environmentally aware input, negative consequences may follow. We are told that "The ecocity is inevitable". 3 Perhaps it is, though Dongtan, a Chinese city project along such lines and one that has attracted a lot of optimistic attention, appears to be running into trouble. ${ }^{4}$ But how about the "ecotown"? There was a lot of UK interest in so-called "garden cities" and "new towns" before and after the 1939-45 war. These were planned entities certainly but in an era when no-one spoke of carbon footprints and the like. The eco-town of today is different. In 2007, the British government announced a process for short-listing and selecting ten sites for such developments, five to be built by 2016 and the rest by $2020 .^{5}$

In no sense are these cities-indeed the housing numbers envisaged for them range from 5,000 to 20,000, so the whole lot would make little impact on another government target of 3 million new homes by 2020. Nevertheless, they do represent new thinking, and those involved have to give weight to several factors not all of which would have been priorities when the former new towns were being planned. Zero carbon status is one ambition. So are sustainable transport and health, the latter presumably being achieved by a cleaner environment (reduced car use, less air pollution) and more opportunities for exercise, the obesity epidemic being one target here. ${ }^{6}$ Forty percent of the area of an eco-town would have to be open space and at least half of that accessible to the public. Walking and the space to practice it ${ }^{7}$ are increasingly being factored into urban planning. A clean drawing-board also provides an opportunity of ensuring that primary care (family practices) is easily accessible. The emphases on local employment and affordable housing mean, or should mean, that an eco-town does not become just another commuter belt.

As 2008 drew to a close, the economic climate seemed hardly conducive to such experiments; indeed, the whole plan may be starting to unravel. ${ }^{8}$ Raising a few eyebrows among cynical political observers, the British government chose the day of the US presidential election result to release the first round of the consultation process on the eco-towns. ${ }^{9}$ On the government's scale of A (a good candidate) to C, only one site would get unqualified approval. This report is being seen as the prelude to a possible climbdown-or at the very least a scaling down of the eco-town

Correspondence: David Sharp, 2 Iron Mills, Minchinhampton, GL69AL, UK. (E-mail: david744 sharp@btinternet.com)

Sharp is a freelance writer in Minchinhampton, UK 
project. Yet, there is considerable support for the basic idea, and some local councils have been backing proposals for their areas. The global economic catastrophe apart, what has gone wrong? That there would be local objections was predictable, especially where a site is "greenfield" rather than a "brownfield" one such as a disused military facility. There are concerns too about the approval process; will the normal planning cycle, which can be prolonged in the UK, be somehow shortened or bypassed for these government-backed schemes? ${ }^{10}$ The criteria for selection are stiff, and rightly so; for instance, an eco-town plan will have to make carbon savings $70 \%$ greater than those required for heating, lighting, and hot water under current building regulations. And how are environmental standards generally to be policed without forms of monitoring that many would find offensive? ${ }^{11}$

To have only one pilot scheme rather than five or ten would be an embarrassment for the politicians but proof that an eco-town can work should encourage more of the same. Furthermore, lessons learned from the smaller project would be relevant to any future thinking about an eco-city.

\section{REFERENCES}

1. Hartig T. Green space, psychological restoration, and health inequality. Lancet. 2008;372:1614-1615.

2. Mitchell R, Popham F. Effect of exposure to natural environment on health inequalities: an observational population study. Lancet. 2008;372:1655-1660.

3. Register R. Short paper for Ecocity World Summit (April, 2008). Accessed on October 20, 2008. http://www.ecocityworldsummit.org/download/2.\%20Basic $\% 20$ info $\% 20$ about $\%$ 20Ecocities.pdf

4. Moore M. China's pioneering eco-city of Dongtan stalls. Accessed on November 8, 2008. http://www.telegraph.co.uk/news/worldnews/asia/china/3223969/Chinas-pioneering-ecocity-of-Dongtan-stalls.html.

5. Department for Communities and Local Government. Eco-towns prospectus. Accessed on November 5, 2008. http://www.communities.gov.uk/publications/housing/ecotownspro spectus.

6. Wintour P. 'Fit towns' to tackle child obesity. The Guardian. Accessed on November 5, 2008. http://www.guardian.co.uk/society/2007/nov/01/health.communities.

7. Sharp D. Australia's new urbanists encourage walking. J Urban Health. 2008;85:457458.

8. Sherman J. Eco-town plan in disarray as sites fail to meet targets. Times (London). Accessed on November 5, 2008. http://www.timesonline.co.uk/news/politics/article 5084309.ece.

9. Department for Communities and Local Government. Eco-towns: living a greener future: summary of consultation process. Accessed on November 5, 2008. http://www.communities. gov.uk/documents/housing/pdf/eco-townsresponsessummary.pdf.

10. Local Government Association. Press release: legal challenge to eco-towns. Accessed on November 5, 2008. http://www.lga.gov.uk/lga/core/page.do? pageId=833451.

11. Booth R. Eco town dwellers may be monitored for green habits. The Guardian. Accessed on November 5, 2008. http://www.guardian.co.uk/environment/2008/sep/26/ecotowns. ethicalliving. 